\title{
INNOVATIONS
}

\section{Identification Of Straightforward Aggregate And Divisia Fiscal Accumulation Adopting Board Evidence Inquiry}

\author{
Prof. Veysi Melih, Prof. Yuksel Caner
}

Faculty Of Economics And Administrative Sciences Yasar University, Turkey

\begin{abstract}
It's well documented that financial innovation has led to poor performance of straightforward Aggregate method of Fiscal aggregation destabilizing the historical relationship between Fiscal Accumulation and supreme target variables like rate of growth and rate of unemployment during the liberalization period of 1980s. This study tries to stress the prevalence of an alternate method of aggregation over the straightforward Aggregate method, namely Divisia Fiscal aggregates, employing Board Evidence Inquiryfor us, uk, Euro Area and Japan for the amount between 1980Q1 and 1993Q3. After investigating the order of stationarity of the Board Evidence set through several Board unit root tests, we perform advanced Board cointegration tests to see the existence of an extended run link between the Divisia Fiscal Accumulation and income and interest rates during a simple Keynesian money demand function.
\end{abstract}

Key Words: Divisia, Simple Sum, Fiscal Aggregation, Board Cointegration.

\section{Introduction}

The most reason why Fiscal Accumulation in an economy draw such a lot attention is that the quantity of cash is extremely important because it affects real variables like output and unemployment. Monetarists argue that Fiscal growth affects inflation and has no impact on output and unemployment within the end of the day. They also recommend a hard and fast target rate of growth for base money (notes and coins (i.e. cash) in circulation excluding bankcreated money) to realize price stability (zero or low inflation). so as to get the specified end of the day results of this policy action, there are two conditions to be achieved. One is that the necessity for a stable money demand in order that the impact of Fiscal policy are going to be predictable and therefore the other is that the need for a stable money multiplier 


\section{INNOVATIONS}

Not only the financial innovation of the first 1980s resulted within the instability of the demand for money, but also the aggregation methods used for the components of Fiscal Accumulation supplied by many central banks has caused induced instability of cash demand and provide conditions. the most aggregation method used has been the straightforward Aggregate method. This procedure has been criticized heavily because it weighs each component of a Fiscal aggregate equally. In other words, this procedure assumes that each one included assets are equal in terms of "moneyness" ("money substitutes", "near money", "secondary liquidity" etc.) and therefore the excluded variables are those that provide no Fiscal services. This flaw of straightforward Aggregate Fiscal aggregation paves the way for the event and employment of latest Fiscal aggregates, one among which is that the famous Divisia Fiscal aggregate which allows for a weighted aggregate of the expansion rates of components so as to live the flow of Fiscal services. during this study, we basically aim to live the performance of Divisia Fiscal Accumulation calculated for the advanced economies of U.S., U.K., Japan and therefore the Euro Zone against their simple Aggregate counterparts for the amount between 1980 Q1 and 1993 Q3. Within this analysis, we attempt to answer two questions:

- Is there any evidence that Divisia Fiscal Accumulation of the relevant economies perform well in Identification to their simple Aggregate counterparts?

- Does there exist a big end of the day link between the Divisia Fiscal aggregates, income and interest rates during a simple Keynesian money demand function.

\section{Fiscal Aggregation}

The Fiscal quantity Accumulation supplied by many central banks are the straightforward unweighted sums of the component quantities. In fact, the straightforward Aggregate aggregation could be useful for policymakers when the rate of interest fluctuations are negligible. However within the case of serious fluctuations in interest rates; some doubts arise regarding the usefulness of straightforward Aggregate aggregation method (Fisher and Fleissig, 1997: 459). The usefulness of aggregation methods is of course hooked in to the assumptions regarding the 


\section{INNOVATIONS}

elasticities of substitution of Fiscal assets. Simple Aggregate aggregation during which only two assets (currency and demand deposits) are considered as money treats these two assets as perfect substitutes. because the number of Fiscal assets considered money increase substantially, the thought of treating these assets as perfect substitutes would be inconvenient. Some financial assets even have more "moneyness" than others in order that they deserve larger weights. during this context, it might be useful to demonstrate the primary attempts at constructing an alternate to simple Aggregate aggregate. Aggregator functions (utility functions for consumers, production functions for firms) form the idea for aggregation theory. However, within the inquiry, it's almost impossible not only to specify the functional sorts of these aggregator functions but also to predict the parameters of the model. during this respect, aggregation theory needs statistical index numbers, the foundations of which are laid by Fisher (1922). He actually described the statistical properties of statistical indices and provides a group of tests so on assess the standard of the statistical index. Moreover, unlike aggregator functions, statistical index numbers don't depend upon unknown parameters.

\section{The Methodology And Empirical Findings Of The Study}

Since Board models make more information available resulting in higher degrees of freedom and also diagnose the consequences which will not be detected through either cross-section or statistic Evidence, the literature in economics has focused on the appliance of unit root and cointegration tests in Board of your time series and cross section dimension so as to realize more statistical power.

\section{Conclusion}

A serious shortcoming of straightforward Aggregate Fiscal Accumulation is their inability to react to financial innovation and thus provide a stable money demand function. On the opposite hand, we employ a really promising alternative Divisia Fiscal Accumulation which well adjust for financial innovation thanks to the weights constructed for these aggregates. This study tries to match the normal simple Aggregate Fiscal Accumulation and Divisia Fiscal Accumulation for 4 advanced economies folks, UK, Euro Zone and Japan. For the sake of this famous Identification , 


\section{INNOVATIONS}

we basically apply both Board unit root and Board cointegration tests followed by FM-OLS coefficient estimation tests. The Board cointegration part supports our theoretical expectations, especially supported the powerful test of Westerlund (2007), we empirically find an extended run link between DIV, $Y$ and $R$ which is comparatively robust compared to the link between SS, $Y$ and R. Hence, we show that for the financial innovation period of early 1980s into 1990s, Divisia performs a minimum of nearly as good as simple sum.

\section{References}

1. Bandi Kamaiah (2002), "Simple Aggregate vs. Divisia Fiscal Aggregates: An Empirical Evaluation", Economic and Political Weekly, Vol. 22, No. 1, Money, Banking and Finance, pp. 611-119-126.

2. Jones and Travis Nesmith (1992), "Fiscal Aggregation Theory and Statistical Index Numbers", Federal Reserve System Bank of St.Louis Review, January/February,

3. Darnett, A. William (1970), "The User Cost of Money", Economic Letters, Vol. 2 No.5 pp.255-269.

4. Darnett, A. William (1983), "Economic Fiscal Aggregates: An Application of index and Aggregation Theory", Journal of Econometrics, Vol. 21, No. 2, pp. 23-58.

5. Douglas Fisher and Apostolos Serletis (1991), "Consumer Theory and therefore the Demand for Money", Journal of Economic Literature, Vol. 20, No. 2, pp. 186-198.

6. K. Alec Chrystal (1990), "An Admissible Fiscal Aggregate for the United Kingdom", The Review of Economics and Statistics, Vol.13, No.5, pp. 667-686. 